\title{
PENGARUH BUDAYA ORGANISASI TERHADAP KINERJA INDIVIDU DENGAN PENERAPAN SISTEM INFORMASI AKUNTANSI SEBAGAI VARIABEL INTERVENING
}

\author{
Bq. Anggun Hilendri L, Nurabiah, Aditya Fajar FR
}

Fakultas Ekonomi dan Bisnis Universitas Mataram

\begin{abstract}
The objective of this study is to examine the influence of organizational culture on individual performance with accounting information system application as intervening variable. This study uses primary data obtained through the distribution of questionnaires to respondents, who are employees working on the clothing distribution store or outlet (Distro) in the Mataram city. The sample of this study consisted of 102 respondents, which is determined based on purposive sampling method. The results of this study indicate that organizational culture has a significant and positive influence on individual performance. Organizational culture also has a significant and positive influence on accounting information system application. However, the application of accounting information system as intervening variable has no influence on individual performance. Likewise the study also found that application of accounting information systems has no indirect influence of organizational culture on the performance of individuals. Businessmen who apply accounting information system in the form of application of accounting software especially on the distrocould use the result of this research, as well as employees as the user of the accounting software in order to understand in advance the steps to apply it thoroughly.
\end{abstract}

Keywords: Organizational culture, accounting information system application, individual performance.

\section{Latar Belakang}

\section{PENDAHULUAN}

Kota Mataram sebagai kota yang berkembang pesat, memiliki pertumbuhan ekonomi yang cukup baik dari tahun ke tahun. Berdasarkan Badan Pusat Statistik Kota Mataram, pertumbuhan ekonomi Kota Mataram pada tahun 2015 mencapai 7,99\%. Pertumbuhan yang tinggi ini didorong oleh semua sektor perekonomian di Kota Mataram. Pendorong pertumbuhan ekonomi tersebut salah satunya ialah perkembangan perusahaan industri kreatif, khususnya distribution store atau distribution outlet atau biasa disebut dengan distro yang mulai berkembang pesat di Kota Mataram yang tentunya juga didorong oleh aktivitas tren di era 
modern ini. Distro umumnya merupakan industri kecil dan menengah (IKM) yang sandang dengan merk independen yang dikembangkan kalangan muda. Produk yang dihasilkan oleh distro diusahakan untuk tidak diproduksi massal, agar mempertahankan sifat eksklusif untuk suatu produk dan hasil kerajinan.

Produk yang dipasarkan oleh distro pada umumnya adalah produk fashion, design dan kerajinan tangan yang merupakan brand lokal hasil kreasi dan produksi oleh pengusaha yang ada pada distro itu sendiri. Diawali pada tahun 1999, distro yang pertama di buka di Kota Mataram adalah Lombok Hardcore (lombokpost.net diakses pada 28 Desember 2016). Kemudian perlahan banyak pengusaha yang mulai bergulir dibidang kreatif ini. Berdasarkan data dari Lombok Clothing Community (LCC), pada tahun 2016 jumlah distro yang terdaftar sebagai anggota komunitas sebanyak 71 Distro lokal. Jumlah ini sangat meningkat jika dilihat pada tahun 2011 hanya 17 Distro saja.

Selain itu di Kota Mataram telah diadakan sebuah event tahunan yang bertajuk tentang festival pakaian branded yang diberi nama Lombok Clothing Festival atau disingkat Locofestyang dalam hal ini telah didukung penuh oleh Dinas Pariwisata Provinsi Nusa Tenggara Barat. Locofest kembali diadakan di Eks Bandara Selaparang Kota Mataram pada tahun 2017 yang dalam acara tersebut terdapat puluhan branded lokal maupun dari luar Kota Mataram. Jika dilihat dari perkembangan distro tersebut yang berbanding lurus dengan laju pertumbuhan ekonomi Kota Mataram, maka dapat disimpulkan bahwa perkembangan industri kreatif sangat mendorong pertumbuhan ekonomi di daerah tersebut.

Melihat hal tersebut, para pengusaha berfikir seribu kali untuk membuat distronya menjadi yang terunggul di dalam persaingan yang kompetitif. Mereka berusaha mencari ide-ide kreatif baru yang dianggap sebagai solusi untuk keberlangsungan usahanya, mulai dari pengembangan ide-ide produk, pemasaran melalui jejaring sosial hingga perbaikan sistem pencatatan dengan menggunakan teknologi komputer, tentunya hal tersebut dapat mempermudah aktivitas perusahaannya. Teknologi tersebut adalah sebuah teknologi komputer yang digunakan dalam memproses dan menyimpan serta teknologi komunikasi yang digunakan untuk mengirim informasi dalam suatu organisasi. (Martin, et al, 2002)

Perbaikan sistem pencatatan dengan menggunakan teknologi adalah salah satunya, yaitu merujuk pada sistem informasi akuntansi. Penguasaan dan penerapan teknologi Sistem Informasi Akuntansi di perusahaan dapat memberikan nilai tambah bagi pengguna yang pada akhirnya berdampak positif pada peningkatan kinerja individual (Romney \& Steinbart, 2012). Salah satu fungsi penting sistem informasi akuntansi adalah pengendalian internal. Salah satu objek pengendalian internal adalah kinerja perusahaan dan kinerja indivdu didalamnya. Kinerja diartikan sebagai kualitas dan kuantitas dari hasil kerja yang telah dicapai oleh pegawai dalam 
melaksanakan tugasnya sesuai dengan tanggung jawabnya (Mangkunegara, 2002).

Keberhasilan suatu perusahaan sangat erat kaitannya dengan kualitas kinerja para anggotanya, sehingga perusahaan dituntut untuk selalu mengembangkan dan meningkatkan kinerja dari para karyawannya. Maka dari itu, penerapan budaya organisasi yang baik akan mempengaruhi kinerja individu yang dalam hal ini adanya pengembangan berbagai teori yang bertujuan untuk meningkatkan keunggulan dan potensi yang dimiliki oleh SDM suatu perusahaan.

Berdasarkan penjelasan tersebut, banyak penelitian sebelumnya yang melakukan penelitian mengenai variabel-variabel budaya organisasi, pemanfaatan sistem informasi akuntansi dan kinerja individu yang antara lain, Penelitian sebelumnya yang dilakukan oleh Suhud (2015) yang menguji pengaruh sistem informasi akuntansi terhadap kinerja individu dan sistem informasi akuntansi didefinisikan atas empat variabel, yaitu pemanfaatan, kualitas, keamanaan dan sarana pendukung sistem informasi akuntansi. Namun tidak semua variabel tersebut berpengaruh terhadap kinerja individu.

Selanjutnya penelitian Widjanarko (2015) tentang pengaruh budaya organisasi terhadap implementasi sistem informasi akuntansi dan implikasinya pada kualitas informasi, hasilnya adalah budaya organisasi memengaruhi implementasi sistem informasi pada perusahaan secara signifikan atau berpengaruh positif. Lalu dalam penelitian Rizaldi (2015) tentang pengaruh sistem informasi akuntansi terhadap Kinerja Individu, dimana implementasi sistem informasi akuntansi sangat signifikan terhadap kinerja individu karyawan CV Teguh Karya Utama Surabaya. Lalu dalam penelitian Yunus (2013) tentang pengaruh sistem informasi akuntansi terhadap kinerja keuangan dengan sistem informasi akuntansi berpengaruh positif signifikan terhadap kinerja keuangan dinas kesehatan Provinsi Gorontalo.

Hasil studi yang menguji tentang pengaruh kinerja individu adalah hasil studi Nako (2016) yang menyatakan bahwa implementasi sistem informasi akuntansi berpengaruh terhadap kinerja individual. Rosydi (2013) dan Suryadi (2013) mengemukakan bahwa budaya organisasi berpengaruh positif terhadap kinerja individu. Dalam penelitian lainnya, Wibowo (2016) dan Putra (2016) menyatakan bahwa kinerja individu mendapatkan pengaruh yang signifikan dari proses uji implikasi antara budaya organisasi dan motivasi terhadap kepuasan pelanggan.

Studi yang meneliti tentang budaya organisasi terhadap kinerja individu adalah Pratama (2012) yang menguji tentang pengaruh budaya organisasi terhadap kinerja pegawai, variabel yang diteliti mempunyai korelasi yang cukup berarti dan berpengaruh positif atau searah. Lalu dalam penelitian Alindra (2015) 
dikemukakan bahwa budaya organisasi berpengaruh positif terhadap kinerja karyawan Depok Sports Center.

Berdasarkan penjelasan dan beberapa hasil penelitian tersebut, penelitian ini akan mengembangkan hasil dari penelitian Suhud (2015) dan mengeksplorasi beberapa kebaruan sebagai berikut: Pertama, berdasarkan kajian literatur belum ada yang menempatkan penerapan sistem informasi akuntansi sebagai variabel mediasi dengan dua taksonomi. Kedua, semakin banyak perusahaan distro yang ada di Kota Mataram saat ini menerapkan sistem informasi akuntansi sebagai alat menjalankan bisnisnya, sehingga menarik untuk diteliti. Ketiga, penelitian ini menggunakan modifikasi taksonomi yang dilakukan dengan menambahkan second order confirmatory factor analysis (CFA) terhadap variabel penerapan sistem informasi akuntansi yang di uji dengan pendekatan Structural Equation Model menggunakan Smart PLS sehingga dapat merefleksikan konstruk yang diuji melalui indikator-indikator secara lebih komprehensif.

\section{Rumusan Masalah}

1. Apakah Budaya Organisasi dapat berpengaruh terhadap Kinerja Individu pada distro di Kota Mataram?

2. Apakah Budaya Organisasi dapat berpengaruh terhadap Penerapan Sistem Informasi Akuntansi pada distro di Kota Mataram?

3. Apakah Penerapan Sistem Informasi Akuntansi dapat berpengaruh terhadap Kinerja Individu pada distro di Kota Mataram?

4. Apakah Budaya Organisasi dapat berpengaruh terhadap Kinerja Individu melalui Pemanfaatan Sistem Informasi Akuntansi pada distro di Kota Mataram?

\section{Tujuan Penelitian}

1. Untuk mengetahui pengaruh Budaya Organisasi terhadap Kinerja Individu pada distro di Kota Mataram.

2. Untuk mengetahui pengaruh Budaya Organisasi terhadap Penerapan Sistem Informasi Akuntansi pada distro di Kota Mataram.

3. Untuk mengetahui pengaruh Penerapan Sistem Informasi Akuntansi terhadap Kinerja Individu pada distro di Kota Mataram

4. Untuk mengetahui pengaruh Budaya Organisasi terhadap Kinerja Individu melalui Kualitas Sistem Informasi Akuntansi pada perusahaan distro di Kota Mataram

\section{Manfaat Penelitian}

1. Secara teoritis sebagai wahana mengembangkan ilmu akuntansi khususnya sistem informasi akuntansi.

2. Secara praktis penelitian ini diharapkan bermanfaat bagi para peneliti berikutnya sebagai salah satu acuan yang mungkin dapat digunakan untuk penelitian dibidang 
akuntansi pada industri kreatif di masa yang akan datang dan para pengusaha Distro dalam mengembangkan usahanya.

\section{KAJIAN PUSTAKA DAN PENGEMBANGAN HIPOTESIS}

\section{Kajian Teoritis Theory of Reasoned Action}

Theory Reasoned Action pertama kali dicetuskan oleh Ajzen pada tahun 1980. Teori ini disusun menggunakan asumsi dasar bahwa manusi berperilaku dengan cara yang sadar dan mempertimbangkan segala informasi yang tersedia. Dalam TRA ini, Ajzen menyatakan bahwa niat seseorang untuk melakukan suatu perilaku menentukan akan dilakukan atau tidak dilakukannya perilaku tersebut. Lebih lanjut, Ajzen mengemukakan bahwa niat melakukan atau tidak melakukan perilaku tertentu dipengaruhi oleh dua penentu dasar, yang pertama berhubungan dengan sikap (attitude towards behavior) dan yang lain berhubungan dengan pengaruh sosial yaitu norma subjektif (subjective norms). Kinerja seseorang mengenai perilaku tertentu ditentukan oleh tujuan untuk menjalankan perilaku, dan tujuan tersebut ditentukan oleh sikap dan norma subyektif (Davis et al,1989:18).

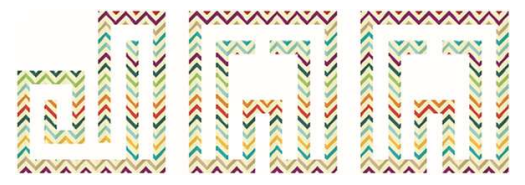

Gambar: TRA dalam penggunaan Sistem Informasi Akuntansi

Jika dihubungkan dengan teori tersebut maka dalam penelitian ini perilaku memengaruhi minat dan niat sebagai alasan pemilik distro dalam memanfaatkan teknologi informasi, dalam hal ini ialah penggunaan software akuntansi yang tentunya dipengaruhi oleh sikap dan norma subyektif dalam bentuk kepercayaan tentang konsekuensi atau akibat dalam menerapkan sistem informasi akuntansi di dalam distronya, antara lain dengan mempertimbangkan persepsi atau pemikiran yang ada, yaitu persepsi risiko, persepsi kemudahan, persepsi manfaat dan persepsi kontrol dari penerapan sistem informasi akuntansi itu sendiri yang pada akhirnya memberikan hasil berupa kepuasan atau ketidakpuasan terhadap tindakan perilaku dari penerapan sistem informasi akuntansi yang dilakukan sehingga akan menerapkan lebih lanjut atau tidak.

\section{Technology Acceptance Model}

TAM yang diperkenalkan oleh Davis (1989) dibangun untuk menjelaskanbagaimana pengguna atau user dapat menerima suatu teknologi dalam sistem informasi. TAM merupakan pengembangan dari Theory Reasoned Action yang diperkenalkan oleh Fishben dan Ajzen (1980). 


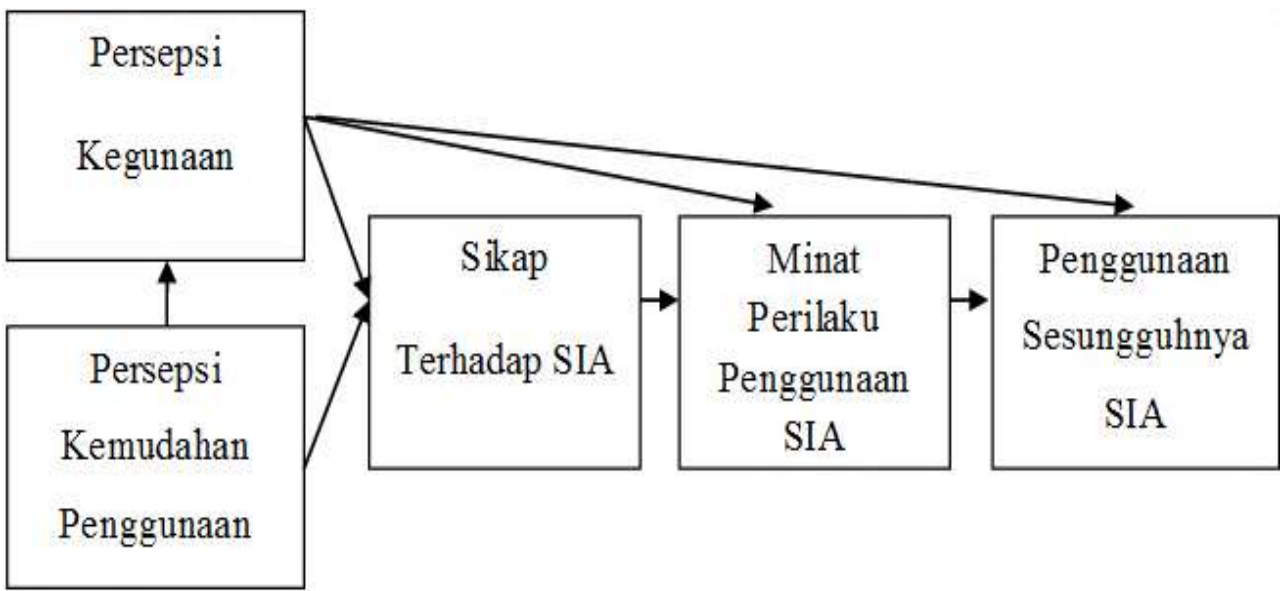

Gambar: TAM dalam penggunaan Sistem Informasi

Akuntansi

Penggunaan Technology Accepted Model (TAM) sebagai salah satu landasan teori dalam penelitian ini adalah untuk menganalisis pengaruh penerapan sistem informasi akuntansi yang terbagi ke dalam dua variabel intervening, yaitu pemanfaatan sistem informasi akuntansi, kualitas sistem informasi akuntansi terhadap kinerja individu serta budaya organisasi yang sesuai dengan Technology Accepted Model(TAM) tersebut, khususnya pada dimensi persepsi kegunaan (Perceived Usefulness).Yang dalam penelitian ini, pemanfaatan sistem informasi akuntansi dan kualitas sistem informasi akuntansi ditentukan sebagai variabel intervening.

\section{The D\&M Information Success Model}

The D\&M Information Success Model menganalisis keberhasilan dari efektivitas penggunaan sistem informasi akuntansi terhadap penerima informasi. Pada model ini, kualitas sistem mengukur keberhasilan teknis, kualitas informasi mengukur keberhasilan semantik, penggunaan, kepuasan pengguna, dampak individual, dan dampak organisasional mengukur keberhasilan efektivitas.

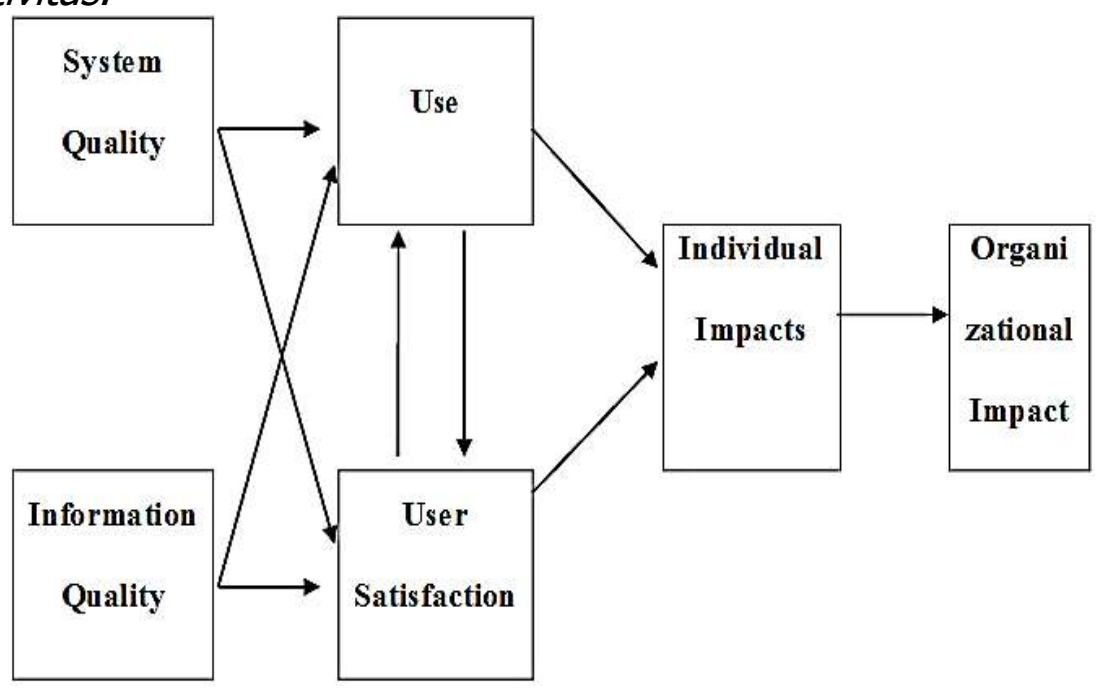




\section{Gambar: The D\&M Information Success Model}

Model digunakan sebagai salah satu landasan teori dalam penelitian ini karena berperan dalam menganalisis efektivitas sistem informasi akuntansi. Efektivitas sistem informasi akuntansi dapat diukur melalui kinerja organisasional yang dihasilkan oleh kualitas sistem informasi akuntansi, kualitas informasi, serta penggunaan dan kepuasan pengguna atas sistem informasi akuntansi yang akan berdampak pada kinerja individu pegawai dan pada akhirnya akan berdampak pada kinerja organisasi tersebut. Kualitas sistem (Sistem Quality) digunakan untuk mengukur kualitas sistem teknologi informasinya sendiri.

Dalam penelitian ini, diharapkan dapat melihat bagaimana penggunaan software akuntansi pada distro dapat meningkatkan produktivitas dalam bisnis distro mereka melalui kesuksesan dari implementasi sistem informasi akuntansi tersebut.

\section{Kajian Konsep \\ Sistem Informasi Akuntansi}

Menurut Romney dan Steinbart (2012) sistem adalah rangkaian dari dua atau lebih komponen-komponen yang saling berhubungan yang berinteraksi untuk mencapai satu tujuan. Sistem umumnya terbagi dalam beberapa subsistem yang memiliki dan menjalankan fungsi khusus yang berguna dalam menopang sistem pusat. Sistem informasi akuntansi memiliki lima komponen, yaitu (1) orang-orang yang mengoperasikan sistem dan melaksanakan berbagai fungsi, (2) prosedur, baik manual maupun yang terotomatisasi yang dilibatkan dalam mengumpulkan dan memproses serta menyimpan data tentang aktivitas organisasi, (3) data tentang proses bisnis perusahaan, (4) software yang dipakai untuk memproses data perusahaan dan (5) infrastruktur teknologi informasi, yaitu termasuk komputer, peralatan pendukung dan jaringan komunikasi.

\section{Pemanfaatan Sistem Informasi Akuntansi}

Pemanfaatan Sistem Informasi Akuntansi merupakan sebuah pelaksanaan tugas-tugas akuntansi yang dilakukan pada aktivitas perusahaan yang terbagi atas beberapa subsistem dari Sistem Informasi Akuntansi, yaitu (Hall, 2009) : (1) Sistem pemrosesan transaksi; (2) Sistem buku besar atau pelaporan keuangan; (3) Sistem pelaporan manajemen. Hasil yang dapat diperoleh dengan pemanfaatan sistem informasi akuntansi adalah sebuah informasi. Informasi merupakan data yang telah diatur dan diproses untuk memberikan arti (Romney \& Steinbart, 2012).

\section{Kualitas Sistem Informasi Akuntansi}

Kualitas sistem dan kualitas informasi yang dihasilkan akan menentukan bagaimana penggunaan dan kepuasan pengguna atas 
penerapan sistem informasi akuntansidalam perusahaan. Kemudian hal tersebut akan berdampak pada kinerja dariindividu, dan selanjutnya akan memengaruhi kinerja perusahaan. Kualitas sistem informasi akuntansi merujuk pada kualitas software yang digunakan di perusahaan. Keberadaan software dipercaya dapat mempermudahproses akuntansi sebagai pelengkap penggunaan komputer. Beberapa kriteriasoftware yang dapat digunakan pada perusahaan adalah mudah dimengerti sertadapat meningkatkan relevansi, akurasi, keringkasan, kelengkapan, dan ketepatanwaktu bagi laporan perusahaan . Salah satu software yang umum digunakan adalah Microsoft Excel. Software tersebut memiliki fitur sederhana yang dapat digunakan oleh pengguna awam secara mudah, tanpa harus mengikuti pelatihan khusus.

\section{Budaya Perusahaan}

Robbins dan Judge (2008:256) mendefinisikan budaya organisasi sebagai sebuah sistem makna bersama yang dianut oleh para anggota yang membedakan suatu organisasi dari organisasi-organisasi lainnya. Robbins dan Judge (2008:258) menyatakan budaya suatu organisasi dibangun dan dipertahankan. Tindakan dari manajemen puncak akan menentukan perilaku umum yang dapat diterima dan yang tidak. Karyawan harus disosialisasikan baik pada tingkat sukses yang dicapai, mencocokkan nilainilai karyawan baru dengan nilai-nilai organisasi.

\section{Kinerja Individu}

Kinerja berasal dari bahasa Inggris performance yang artinya performa. Konsep kinerja merupakan singkatan dari kinetika energi kerja. Secara etimologi, kinerja berasal dari kata prestasi kerja (performance). Sebagaimana dikemukan oleh Mangkunegara (2007) bahwa istilah kinerja dari kata kata job performance atau actual performance (prestasi kerja atau prestasi sesungguhnya yang dicapai oleh seseorang) yaitu hasil kerja secara kualitas dan kuantitas yang dicapai oleh seorang pegawai dalam melaksanakan tugasnya sesuai dengan tanggung jawab yang diberikan padanya.

\section{Pengembangan Hipotesis}

\section{Pengaruh Budaya Organisasi terhadap Kinerja Individu}

Budaya organisasi pada hakekatnya merupakan salah satu unsur pendukung dalam meningkatkan kinerja karyawan. Organisasi yang memperhatikan unsur budaya organisasi tersebut akan meningkatkan kualitas dari organisasi. Budaya organisasi menjadi salah satu pedoman kerja untuk meningkatkan kinerja karyawan menjadi lebih optimal. Menurut Robbins (2009) Hampir tidak ada keraguan bahwa budaya organisasi sangat berpengaruh terhadap kinerja karyawan. Maka dari itu untuk mencapai kerja yang professional, manajemen dan divisi sumber daya 
manusia harus bisa menciptakan budaya kerja organisasi yang berkualitas. H1 : Budaya Organisasi berpengaruh positif terhadap kinerja individu.

\section{Pengaruh Budaya Organisasi terhadap Penerapan Sistem Informasi Akuntansi}

Theory of Reasoned Action mengatakan bahwa penggunaan teknologi komputer dapat meningkatkan kinerja individu. Setelah ditelaah, bahwa budaya organisasi menjadi pembentuk struktur penting dalam perkembangan sistem informasi maupun kinerja individu. Robbins and Judge (2008) mendefinisikan Budaya Perusahaan sebagai sebuah sistem makna bersama yang dianut oleh para anggota yang membedakan suatu organisasi dari organisasi-organisasi lainnya. Budaya perusahaan sebagai acuan baku yang diberlakukan oleh suatu perusahaan, dimana budaya perusahaan yang sistematis menuntun para karyawan untuk meningkatkan komitmen kerjanya bagi perusahaan, sehingga menghasilkan karyawan yang profesional.

H2: Budaya organisasi berpengaruh positif terhadap Penerapan Sistem Informasi Akuntansi

\section{Pengaruh Penerapan Sistem Informasi Akuntansi terhadap Kinerja Individu}

Theory of Reasoned Action mengatakan penggunaan komputer dipercaya dapat meningkatkan kinerja individu. Hal tersebut dibahas kembali dalam konsep Technology Acceptance Model (TAM), yaitu pada dimensi Persepsi Kegunaan (Perceived usefulness). Lebih lanjut dalam model $T A M$,persepsi kegunaan ini akan memengaruhi seorang pegawai untuk menggunakan sistem informasi akuntansi yang merupakan bagian dari suatu teknologi informasi. Selain itu, pengaruh penggunaan atau pemanfaatan sistem informasi akuntansi terhadap kinerja individu juga dijelaskan oleh The D\&M Information Sistem Success Model. Pada teori ini dijelaskan bahwa penggunaan atau pemanfaatan Sistem informasi akuntansi akan menimbulkan kepuasan pengguna yang akan berdampak pada kinerja individu dan kinerja organisasi.

H3: Penerapan Sistem Informasi Akuntansi berpengaruh positif terhadap Kinerja Individu

\section{Pengaruh Budaya Organisasi terhadap Kinerja Individu melalui Penerapan Sistem Informasi Akuntansi}

Theory of Reasoned Action mengatakan bahwa penggunaan teknologi komputer dapat meningkatkan kinerja individu. Setelah ditelaah, bahwa budaya organisasi menjadi pembentuk struktur penting dalam perkembangan sistem informasi maupun kinerja individu. Robbins and Judge (2008) mendefinisikan Budaya 
Perusahaan sebagai sebuah sistem makna bersama yang dianut oleh para anggota yang membedakan suatu organisasi dari organisasi-organisasi lainnya. Budaya perusahaan sebagai acuan baku yang diberlakukan oleh suatu perusahaan, dimana budaya perusahaan yang sistematis menuntun para karyawan untuk meningkatkan komitmen kerjanya bagi perusahaan, sehingga menghasilkan karyawan yang profesional.

H4: Budaya Organisasi berpengaruh positif terhadap Kinerja Individu melalui Penerapan Sistem Informasi Akuntansi

\section{Rerangka Konseptual}

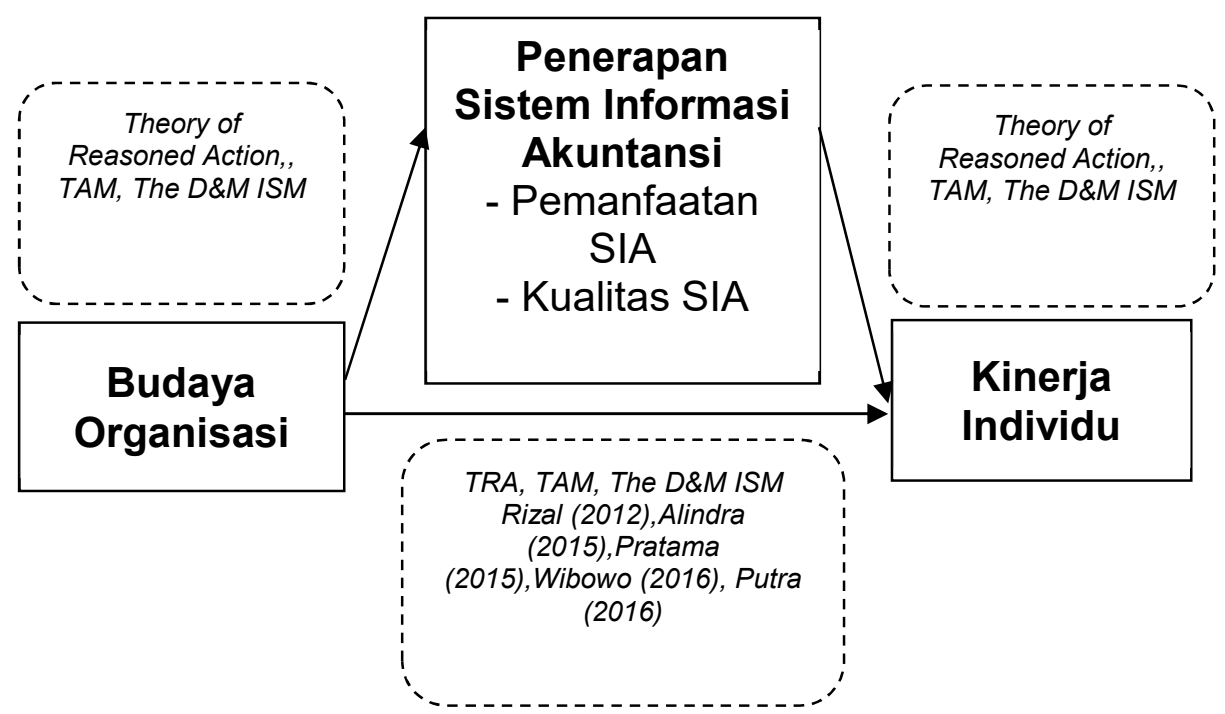

Gambar: Rerangka Konseptual Sumber : Data Sekunder, 2017 


\section{METODE PENELITIAN}

Jenis penelitian ini adalah penelitian asosiatif dengan menggunakan pendekatan kuantitatif. Kota Mataram dipilih sebagai lokasi penelitian, karena merupakan awal munculnya distro di NTB. Selain itu, beberapa aktivitas tahunan telah diadakan di Kota Mataram, mulai dari Locofest Selaparang hingga Mini Locofest Epicentrum. Bahkan dukungan dari pemerintah daerah sudah terealisasi dengan dicantumkannya event tahunan Locofestini ke dalam kalender acara Dinas Pariwisata Provinsi Nusa Tenggara Barat. Populasi dalam penelitian ini adalah seluruh distro yang terdapat di Kota Mataram. Adapun alasan pemilihan distro sebagai populasi penelitian ini dikarenakan distro itu sendiri sekarang menjadi sebuah aktivitas tren di era modern saat ini, khususnya dalam bidang industri kreatif bahkan telah dibuktikan dengan adanya dukungan dari Dinas Pariwisata NTB, selain itu kemudahan akses penelitian juga menjadi alasan yang kuat dalam penentuan populasi ini. Total populasi dari penelitian ini sebanyak 71 distro.

Pengambilan sampel dalam penelitian ini dilakukan dengan metode purposive sampling. Sampel dari penelitian ini adalah distro yang pemiliknya berdomisili di Kota Mataram. Menurut data dari Lombok Clothing Community, anggota yang terdaftar serta aktif sebanyak 71 distro dan sebanyak 34 distro berada di Kota Mataram. Kriteria penentuan sampel distro adalah sebagai berikut: a) Distro yang berdomisili di Kota Mataram, b) Telah menggunakan aplikasi sistem informasi akuntansi. Selanjutnya penetapan jumlah responden ialah seluruh karyawan yang langsung menggunakan sistem informasi akuntansi atau yang bekerja sebagai cashier pada distribution outlet yang berada di Kota Mataram yang berkisar 3 orang karyawan pada setiap distro. Jumlah sampel distro ini dapat dilihat pada Tabel 3.1.

Tabel: Sampel

\begin{tabular}{|l|c|c|}
\hline \multicolumn{1}{|c|}{ Keterangan } & $\begin{array}{c}\text { Jumlah } \\
\text { Distro }\end{array}$ & $\begin{array}{c}\text { Jumlah } \\
\text { Cashier }\end{array}$ \\
\hline $\begin{array}{l}\text { Jumlah Distro yang terdaftar di Lombok Clothing } \\
\text { Community }\end{array}$ & 71 & $71 \times 3=213$ \\
\hline $\begin{array}{l}\text { Jumlah Distro yang tidak berdomisili di Kota } \\
\text { Mataram }\end{array}$ & $(37)$ & $(37) \times 3=(111)$ \\
\hline $\begin{array}{l}\text { Jumlah Distro yang berdomisili di Kota } \\
\text { Mataram }\end{array}$ & $\mathbf{3 4}$ & $\mathbf{3 4 \times 3 = 1 0 2}$ \\
\hline
\end{tabular}

Sumber : Data Sekunder, 2017

\section{Definisi Operasional Variabel}

\section{a. Budaya Organisasi}

Budaya organisasi adalah sebuah sistem makna bersama oleh para anggota yang membedakan suatu organisasi dari organisasi-organisasi lainnya (Robbins dan Judge 2008). Variabel Budaya Organisasi ditempatkan sebagai 
variabel dependen. Indikator yang digunakan untuk mengukur variabel budaya organisasi adalah karakter budaya organisasi menurut Robbins dan Coulter (2012) 1) Inovasi dan keberanian mengambil resiko, 2) perhatian pada detail, 3) berorientasi hasil, 4) berorientasi orang, 5) berorientasi tim, 6) keagresifan, dan 7) stabilitas.. Variabel ini diukur dengan 7 Indikator dan total 14 pertanyaan dan menggunakan skala likert (1-4).

\section{b. Kinerja Individu}

Kinerja Individu adalah catatan keberhasilan dari suatu pekerjaan / tugas yang telah dicapai seorang karyawan dalam kurun waktu tertentu, melalui proses penilaian kinerja juga merupakan hasil yang bersifat kualitatif dan kuantitatif. (Bernardin dan Russel (1993:382). Indikator variabel kinerja individu daloam penelitian ini merujuk pada Bernadin dan Russel (1993) dimana terdapat 6 (enam) kategori untuk mengukur Kinerja Individu yaitu (1) Kualitas, (2) Kuantitas, (3) Ketepatan waktu,

(4) Kemandirian dan (5) Percaya diri. Variabel ini diukur dengan 5 Indikator dan total 10 pertanyaan dan menggunakan skala likert (1-4).

\section{c. Pemanfaatan Sistem Informasi Akuntansi}

Pemanfaatan Sistem Informasi Akuntansi adalah sebuah pelaksanaan tugas-tugas akuntansi yang dilakukan pada aktivitas perusahaan yang terbagi atas beberapa subsistem dari Sistem Informasi Akuntansi, yaitu (Hall, 2009) :

1. Sistem pemrosesan transaksi.

2. Sistem buku besar atau pelaporan keuangan

3. Sistem pelaporan manajemen

Pemanfaatan sistem informasi akuntansi yang dimaksud dalam penelitian ini adalah aplikasi software akuntansi. Untuk menguji variabel ini digunakan beberapa indikator sebagai berikut : (a) Input, (b) Process dan (c) Output. Variabel ini diukur dengan 3 Indikator dan total 7 pertanyaan dan menggunakan skala likert (1-4).

\section{d. Kualitas Sistem Informasi Akuntansi}

Kualitas sistem informasi yang dimaksud dalam penelitian ini adalah kualitas softwareakuntansi yang digunakan, dilihat dari persepsi pemakai.Kualitas sistem informasi akuntansi dapat dibagi ke dalam beberapa dimensi yang juga digunakan sebagai indikator variabel. Hal ini dijabarkan oleh Garvin (1988) yaitu: (a)Performance (kinerja); (b) Features (fitur); (c) Reliability (kehandalan) (d) Conformance (kesesuaian);(e) Durability (ketahanan), (f) Serviceability (kemudahan perbaikan) (g) Aesthetics (estetika/keindahan), (h) Perceived quality,(kualitas yang diterima oleh pengguna). Variabel ini diukur dengan 7 Indikator dan total 16 pertanyaan dan menggunakan skala likert (1-4).

\section{Prosedur Analisis Data}

Pengujian hipotesis digunakan teknik Partial Least Square (PLS) 
menggunakan aplikasi smart PLS 3.0. Diagram jalur dari persamaan outer mode/ dan inner mode/ dalam penelitian ini adalah sebagai berikut :

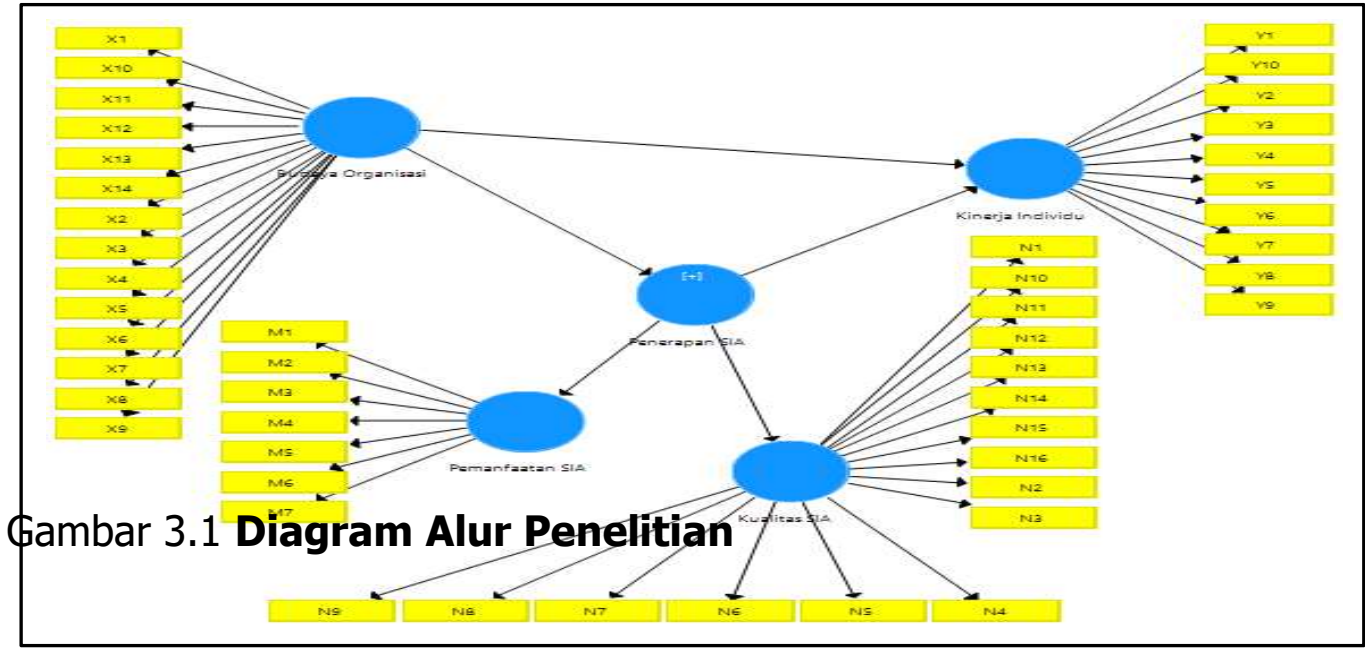

\section{Keterangan:}

$\begin{array}{ll}\text { BO } & \text { : Budaya Organisasi } \\ \text { KI } & \text { : Kinerja Individu } \\ \text { PnSia } & \text { : Penerapan SIA } \\ \text { P. SIA } & \text { :PemanfaatanSistem Informasi Akuntansi } \\ \text { K. SIA } & \text { : Kualitas Sistem Informasi Akuntansi }\end{array}$

Bentuk persamaan outer model dalam penelitian ini disajikan dalam tabel berikut:

1. Model $1 \mathrm{BO} \longrightarrow$ P.SI

$\mathrm{BO}=\lambda_{11} \mathrm{BO} \cdot \mathrm{X} 1+\lambda_{12} \mathrm{BO} \cdot \mathrm{X} 2+\lambda_{13} \mathrm{BO} \cdot \mathrm{X} 3+\lambda_{14} \mathrm{BO} \cdot \mathrm{X} 4+\lambda_{15} \mathrm{BO} \cdot \mathrm{X} 5+\lambda_{16} \mathrm{~B}$

O.X6 $+\lambda_{17} \mathrm{BO} . \mathrm{X} 7+\varepsilon 1$

PSI $=\lambda_{11}$ PSI.M1 $1+\lambda_{12}$ PSI.M2 $+\lambda_{13}$ PSI.M3 $+\varepsilon 2$

2. Model $2 \mathrm{BO} \longrightarrow \mathrm{KSI}$

$\mathrm{BO}=\lambda_{11} \mathrm{BO} \cdot \mathrm{X} 1+\lambda_{12} \mathrm{BO} \cdot \mathrm{X} 2+\lambda_{13} \mathrm{BO} \cdot \mathrm{X} 3+\lambda_{14} \mathrm{BO} \cdot \mathrm{X} 4+\lambda_{15} \mathrm{BO} \cdot \mathrm{X} 5+\lambda_{16} \mathrm{~B}$

O.X6 $+\lambda_{17} B O . X 7+\varepsilon 1$

$\mathrm{KSI}=$

$\lambda_{11}$ KSI.N1 $+\lambda_{12}$ KSI.N2 $+\lambda_{13}$ KSI.N3 $+\lambda_{14}$ KSI.N4 $+\lambda_{15}$ KSI.N5 $+\lambda_{16}$ KS

I.N6+ $\lambda_{17}$ KSI.N7 $+\varepsilon 2$

3. Model $3 \mathrm{BO} \longrightarrow \mathrm{PSI} \longrightarrow \mathrm{KI}$

$\mathrm{BO}=\lambda_{11} \mathrm{BO} \cdot \mathrm{X} 1+\lambda_{12} \mathrm{BO} \cdot \mathrm{X} 2+\lambda_{13} \mathrm{BO} \cdot \mathrm{X} 3+\lambda_{14} \mathrm{BO} \cdot \mathrm{X} 4+\lambda_{15} \mathrm{BO} \cdot \mathrm{X} 5+\lambda_{16} \mathrm{~B}$

O.X6 $+\lambda_{17}$ BO.X7 $+\varepsilon 1$

PSI $=\lambda_{11}$ PSI.M1 $1+\lambda_{12}$ PSI.M2 $+\lambda_{13}$ PSI.M3 $+\varepsilon 2$

$\mathrm{KI}=\lambda_{21} \mathrm{KI} . \mathrm{Y} 1+\lambda_{22} \mathrm{KI} . \mathrm{Y} 2+\lambda_{23} \mathrm{KI} . \mathrm{Y} 3+\lambda_{24} \mathrm{KI} . \mathrm{Y} 4+\lambda_{25} \mathrm{KI} . \mathrm{Y} 5+\varepsilon 3$

4. Model $4 \mathrm{BO} \longrightarrow \mathrm{KSI} \longrightarrow \mathrm{KI}$

$\mathrm{BO}=\lambda_{11} \mathrm{BO} \cdot \mathrm{X} 1+\lambda_{12} \mathrm{BO} \cdot \mathrm{X} 2+\lambda_{13} \mathrm{BO} \cdot \mathrm{X} 3+\lambda_{14} \mathrm{BO} \cdot \mathrm{X} 4+\lambda_{15} \mathrm{BO} \cdot \mathrm{X} 5+\lambda_{16} \mathrm{~B}$

O.X6 $+\lambda_{17}$ BO.X7+ 1 


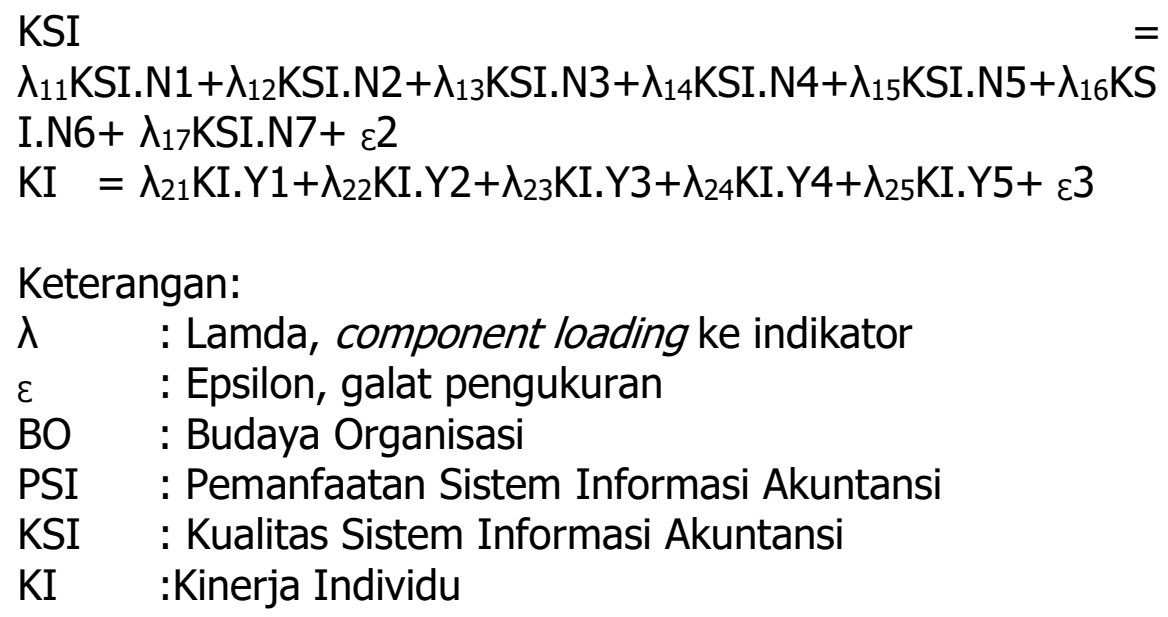

\section{Inner Model:}

Bentuk persamaan inner model dalam penelitian ini adalah sebagai berikut :

1. PSIA $=\gamma_{1} \cdot \mathrm{BO}+\zeta_{1}$

2. $\mathrm{KSIA}=\gamma_{2} \cdot \mathrm{BO}+\zeta_{2}$

3. $\mathrm{KI}=\gamma_{3} . \mathrm{BO}+\beta_{1}$. PSIA $+\beta_{2} . \mathrm{KSIA}+\zeta_{3}$

Keterangan :

$\gamma$ : Gamma, koefisien pengaruh var. eksogen terhadap endogen

$\beta$ : Beta, koefisien pengaruh var. endogen terhadap endogen

$\zeta$ : Zeta,

Pengujian hipotesis mediasi dapat dilakukan dengan prosedur yang dikembangkan oleh Sobel (1982) dan dikenal dengan uji Sobel (Sobel test). Uji sobel dilakukan dengan cara menguji kekuatan pengaruh tidak langsung variabel independen $(X)$ ke variabel dependen ( $Y$ ) melalui variabel intervening ( $M)$. Pengaruh tidak langsung $X$ ke $Y$ melalui $M$ dihitung dengan cara mengalikan jalur $\mathrm{X} \rightarrow \mathrm{M}$ (a) dengan jalur $\mathrm{M} \rightarrow \mathrm{Y}(\mathbf{b})$ atau $\mathbf{a b}$. Jadi koefisien $\mathbf{a b}=\left(\mathbf{c}-\mathbf{c}^{\prime}\right)$, dimana $\mathbf{c}$ adalah pengaruh $X$ terhadap $Y$ tanpa mengontrol $\mathbf{M}$, sedangkan $\mathbf{c}^{\prime}$ adalah koefisien pengaruh $X$ terhadap $Y$ setelah mengontrol M. Standard error koefisien a dan $\mathbf{b}$ ditulis dengan Sa dan $\mathbf{S b}$, besarnya standard error pengaruh tidak langsung (indirect effect) Sab dihitung dengan rumus dibawah ini :

$$
S a b=\sqrt{b^{2} S a^{2}+a^{2} S b^{2}+S a^{2} S b^{2}}
$$

Untuk menguji signifikansi pengaruh tidak langsung, maka kita perlu menghitung nilai t dari koefisien ab dengan rumus sebagai berikut : Nilai t hitung ini dibandingkan dengan nilai t tabel yaitu $>=1,96$.

$$
t=\frac{a b}{S a b}
$$

Jika nilai t hitung lebih besar dari nilai t tabel maka dapat disimpulkan terjadi pengaruh mediasi (Ghozali, 2016). 


\section{HASIL PENELITIAN}

\section{Pengaruh Budaya Organisasi terhadap Kinerja Individu}

Hipotesis 1 yang menyatakan bahwa terdapat pengaruh budaya organisasi terhadap kinerja individu diterima ditunjukkan dengan Kebanyakan distro memiliki budaya organisasi yang menuntut kebiasaan bekerja yang baik dan teratur dalam menerapkan sistem informasi akuntansi dalam hal ini ialah aplikasi software akuntansi. Kebiasaan yang telah tumbuh di dalam distro tersebut memengaruhi setiap individu yang bekerja dalam distro tersebut untuk selalu bekerja secara efektif dan efisien dengan alasan bahwa untuk pencapaian tujuan dari distro tersebut. gaya hidup masyarakat.

\section{Pengaruh Budaya Organisasi terhadap Penerapan SIA}

Hipotesis 2 yang menyatakan bahwa terdapat pengaruh budaya organisasi terhadap penerapan SIA diterima ditunjukkan dengan Distro yang telah menerapkan sistem informasi akuntansi dalam hal ini aplikasi software akuntansi, tentu mengharuskan karyawan yang bekerja disana untuk bisa mengaplikasikan software akuntansi tersebut. Namun karyawan tersebut harus mengetahui manfaat dan kegunaan dari aplikasi software akuntansi tersebut dalam penerapannya saat bekerja. Jika karyawan yang bekerja mengetahui kemudahan yang ia dapatkan saat bekerja, tentu karyawan yang bekerja pada distro tersebut akan menggunakan aplikasi software akuntansi tersebut.

\section{Pengaruh Penerapan SIA terhadap Kinerja Individu}

Hipotesis 3 yang menyatakan bahwa terdapat pengaruh penerapan sistem informasi akuntansi terhadap kinerja individu ditolak, sehingga tidak ada pegaruh antara keduanya karena banyak individu yang bekerja pada distro belum bisa memanfaatkan dengan sepenuhnya, . tentu hal ini disebabkan oleh besar kecil modal dari distro tersebut. Selain itu hal ini diakibatkan karena kurangnya pemahaman untuk mengaplikasikan software akuntansi tersebut karena jika dilihat pada jenjang pendidikan terakhir responden masih sebatas Sekolah Menengah Atas yang mengakibatkan kurangnya pemahaman pada segi pembukuan keuangan tersebut serta ditunjang oleh banyaknya perbedaan softwareseperti Microsoft Excel, Zahir Accounting dan beberapa aplikasi software akuntansi berbayar lainnya pada setiap distro yang tentunya memiliki tingkat kesusahan yang berbeda.

\section{Pengaruh Budaya Organisasi terhadap Kinerja Individu melalui Penerapan Sistem Informasi Akuntansi}

Hipotesis 4 yang menyatakan bahwa terdapat pengaruh budaya 
organisasi terhadap kinerja individu melalui penerapan sistem informasi akuntansi ditolak, sehingga tidak ada pegaruh antara keduanya karena budaya organisasi pada distro yang diteliti adalah sebuah kebiasaan dalam memanfaatkan aplikasi software akuntansi untuk kemudahan individu dalam bekerja. Selain itu, memiliki alasan yang sama pula yakni banyak individu yang bekerja pada distro belum bisa memanfaatkan dengan sepenuhnya. Mulai dari kurangnya pemahaman individu atas aplikasi software akuntansi tersebut akibat responden yang mayoritas jenjang pendidikan terakhirnya masih sebatas Sekolah Menengah yang mengakibatkan kurangnya pemahaman pada segi pembukuan keuangan tersebut serta ditunjang oleh banyaknya perbedaan software seperti Microsoft Excel, Zahir Accounting dan beberapa aplikasi software akuntansi berbayar lainnya pada setiap distro yang tentunya memiliki tingkat kesusahan yang berbeda.

\section{PENUTUP}

\section{Simpulan}

Budaya organisasi yang ada pada setiap distro menuntut karyawan untuk bekerja secara efektif dan efisien walaupun budaya organisasi seperti yang kita ketahui dapat berbeda pada setiap organisasinya karena merupakan suatu ciri dan khas. Budaya organisasi berpengaruh terhadap penerapan sistem informasi akuntansi. karena distro telah banyak yang menerapkan sistem informasi akuntansi berupa aplikasi software akuntansi sistem keuangannya, selain itu distro pun mengharuskan setiap individu untuk bisa memahami dan menggunakan aplikasi tersebut. Penerapan sistem informasi akuntansi tidak berpengaruh terhadap kinerja individu karena kurangnya pemahaman untuk mengaplikasikan software akuntansi tersebut karena jika dilihat pada jenjang pendidikan terakhir responden masih sebatas Sekolah Menengah Atas yang mengakibatkan kurangnya pemahaman pada segi pembukuan keuangan tersebut serta ditunjang oleh banyak perbedaan software pada setiap distro yang tentunya memiliki tingkat kesusahan yang berbeda. Penerapan sistem informasi akuntansi belum mampu memediasi hubungan antara budaya organisasi dengan kinerja individu karena kurangnya pemahaman responden akan aplikasi software akuntansi tersebut, terlebih adanya banyak perbedaan fitur pada tiap software yang digunakan pada masing-masing distro.

\section{Implikasi Penelitian}

Implikasi dari hasil penelitian ini dapat digunakan oleh berbagai pihak seperti, pelaku usaha yang menerapkan sistem informasi akuntansi berupa aplikasi software akuntansi khususnya distro, dan karyawan-karyawan yang ditempatkan untuk memanfaatkan aplikasi software akuntansi. Diharapkan kepada pelaku usaha yang menerapkan sistem informasi akuntansi berupa 
aplikasi software akuntansi khususnya distro, dan karyawan-karyawanyang ditempatkan untuk memanfaatkan aplikasi software akuntansi tersebut dapat memahami terlebih dahulu bagaimana langkah-langkah untuk pengaplikasiannya secara menyeluruh sebelum benar-benar akan digunakan.

\section{Saran Dan Keterbatasan Penelitian}

Pada penelitian ini terdapat beberapa keterbatasan yang nantinya dapat memberi arah bagi penelitian mendatang, yaitu :

1. Pengukuran variabel penerapan sistem informasi akutansi sebagai variabel intervening masih hanya menggunakan dua taksonomi saja sehingga belum mampu mencerminkan kondisi yang lebih akurat mengenai penerapan sistem informasi akuntansi yang dalam hal ini berupa aplikasi software akuntansi. Oleh karena itu, penelitian selanjutnya disarankan dapat menambahkan proksi yang lebih banyak dan tepat untuk mengukur penerapan sistem informasi akuntansi.

2. Diharapkan pada penelitian selanjutnya, pada pengisian data responden diberikan penjelasan mengenai lama waktu bekerja pada setiap distro. Sehingga dapat diketahui seberapa jauh interaksi responden dengan penggunaan aplikasi software akuntansi tersebut.

3. Diharapkan pada penelitian selanjutnya akan lebih banyak memuat penelitian terdahulu untuk lebih menguatkan penelitiannya, sehingga diharapkan pada penelitian selanjutnya dapat lebih banyak penggunaan penelitian terdahulu atas variabel yang digunakan.

\section{DAFTAR PUSTAKA}

Ajzen, I. (1985), From intentions to actions: $A$ Theory of Planned Behavior. Nature and Operation of Attitudes. Annual Review of Psychology, 52, pp. 27-58.

Ajzen, I., Fishbein, M. (1975), Belief, Attitude, Attention and Behavior, An Introduction to Theory and Researc., Addison Wesley Publising Company.

Alindra, Aput Ivan. 2015. Analisis Pengaruh Budaya Organisasi terhadap Kinerja Karyawan Depok Sports Center: Skripsi. Universitas Negeri Yogyakarta.

Badan Pusat Statistik. 2016. Statistik Daerah Kota Mataram Tahun 2016, Catalog 1101002.5271. Badan Pusat Statistik

Bernadin dan Russel. 2013. Human Resource Management. New Jersey : International Editions Upper Saddle River, Prentice Hall

Davis, F.D. (1989). Perceived Usefulness, Perceived Ease of Use and User Acceptance of Information Technology. MIS Quarterly, 13(3): 319339. 
Davis, F.D., Bagozzi, R.P dan Warshaw, P.R. (1989). User Acceptance of Information Technology: A Comparison of Two Theoritical Model. Management Science, 35, 982-1002.

Delone, W.H., McLean, E.R., 1992. Information systems success: the quest for the dependent variable . Information System Research 3 (1), 60-95.

Dita, Made Ambara., Putra, I Wayan. 2016. Pengaruh Penerapan Sistem Informasi Akuntansi terhadap Kinerja Karyawan dengan Integritas Karyawan sebagai Variabel Pemoderasi. Jurnal UNUD Universitas Udayana

Garvin, David A. 1988. Managing quality: the strategic and competitive edge. New York: Free Press.

Ghozali, I. (2015). Structural Equation Modeling Metode Alternatif dengan Partial Least Square (PLS). Semarang. Badan Penerbit Universitas Diponegoro Edisi 2.

Hall, James A. 2013. Accounting Information Systems.7 Ed. South Western Cengage Learning

Mangkunegara, A. P. (2002). Manajemen Sumber Daya Perusahaan. ROSDA, Bandung

Nako, Natalie. 2015. Pengaruh Penerapan Sistem Informasi Akuntansi Terhadap Kinerja Individu Pada Balai Pemantapan Kawasan Hutan Wilayah Xi Jawa - Madura :Skripsi. UniversitasAtma Jaya

Pratama, Yoga (2015), Pengaruh Budaya Organisasi terhadap Kinerja Pegawai pada Kantor Kecamatan Nanggung Kabupaten Bogor. Skripsi. Universitas Indonesia

Rizaldi, Fahmi. 2015. Pengaruh Sistem Informasi Akuntansi terhadap Kinerja Karyawan CV Teguh Karya Utama Surabaya. Jurnal IImu \& Riset Akuntansi Vol. 4 No. 10

Robbins, Stephen dan Judge, Timothy A. 2009. Organizational Behaviour. International ed. Prentice Hall.

Romney, Marshall B. and Paul John Steinbart. 2012. Accounting Information System. 13th edition.Upper Saddle River-New Jersey: PrenticeHall International,Inc

Suhud, Sheilla Puteri. 2015. Pengaruh Sistem Informasi Akuntansi terhadap Kinerja Individu pada Perusahaan Distro di Kota Bandung: Skripsi. Universitas Diponegoro

Suryadi, Ahmad \& Hamim Rosydi.2013. Kinerja Karyawan ditinjau dari Analisis Faktor Budaya Perusahaan. Jurnal Penelitian Psikologi, Vol 4 No. 2. IAIN SunanAmpel Surabaya

Wibowo, Mada Adi dan Yanuar Surya Putra.2016. Pengaruh Motivasi Dan Budaya Organisasi Terhadap Kepuasan Kerja Serta Implikasinya Terhadap Kinerja Karyawan Pada Rumah Sakit Umum (RSU) Salatiga.Jurnal IImiah Among Makarti. STIE AMA 
Wibowo.2016. Manajemen Kinerja : edisikelima. PT. Raja Grafindo Parsada: Jakarta.

Widjanarko, Frita Yanuarti. 2015. Pengaruh Budaya Organisasi Terhadap Implementasi Sistem Informasi Akuntansi Dan Implikasinya Pada Kualitas Informasi :Skripsi. UniversitasPasundan

Yunus, Yuliah Mutmainnah D. 2013. Pengaruh Sistem Informasi Akuntansi Terhadap Kinerja Keuangan Pada Dinas Kesehatan Provinsi Gorontalo : Skripsi. Universitas Negeri Gorontalo

lombokpost.net diakses pada 28 Desember 2016 